\title{
Implementation of Character Education to Improve the Students Discipline Through Habituation of Nadzam Asmaul Husna Recitation at Grade IV
}

\author{
Puji Asih, Ali Sunarso \\ Department of Primary School Teacher Education, Faculty of Education, Semarang State University \\ Corresponding email: asiih.pujji@gmail.com
}

\begin{abstract}
Character education should take place through habituation and all the time in everyday life. This study aims was to determine (1) Implementation of character education (2) Barriers to Reading Asmaul Husna's Habits (3) Supporting reading habits Asmaul Husna (4) Influence of Asmaul Husna on student character. The research was conducted in SDN Purwoyoso 01 Ngaliyan with research subject of fourth-grade students, religious teachers and class teachers on Implementation of Student Discipline Character Education through Reading Asmaul Husna Habituation. The approach used was a qualitative single-case study type. Data collection was done through semi-structured interviews, observation, and documentation. Data analysis was done by using content analysis technique. The result of this research shows that: (1) the discipline of students is good, (2) the implementation of character education through reading habits of Asmaul Husna is good (3) the influence of reading habits of Asmaul Husna has an effect on the character of the students of class IV.
\end{abstract}

Keywords: Character education, discipline, Reading Asmaul Husna Habituation.

\section{Introduction}

Character education is all measures that the teacher takes to influence the students' character. The teacher helps build the character of the students. This covers modelling of the teacher's behavior, how the teacher speaks and delivers the lessons, and the other relevant things. Process of character education is regarded as the conscious and systematic efforts, instead of coincidence measure ( Zubaedi, 2015:14).

Perpres nomor 87 Tahun 2017 (Presidential Regulation:87/2007) on Encouragement of Character Education is the solution to particular problems in education world. The regulation aims to build and to provide the students, as golden generation of Indonesia in 2045, with the spirit of Pancasila and proper Character Education in order to face the dynamics of the future. The character education has to run through habituation in daily life all the time.

Character education is not limited by time and space. Anywhere and anytime, the of character education process must be gone through and be made habit.

One of the characters that need to be built is discipline. Discipline as a character value is important for humankind to generate the other good characters. The importance of the strengthening of the self-discipline values underlies on the fact that today aberrant behavior that is contrast to self-discipline, emerged.

Dewi Emiasih (2011) in her study stated that the school as the secondary institution following family that plays important role in instilling the life values to individuals. Character education improves the students' self-discipline, the school must make contribution to the curriculum design of the character education. One of the habituation activities carried out in SDN Purwoyoso 01 is reciting nadzam asmaul husna led by the teacher from the teacher's office using the amplifier and followed by all the students at grade 1-6 in their respective classroom. This kind of activity makes the students discipline. During the habituation process some students was not discipline, many did not followed in orderly way, did not know asmaul husna, played with his friend, and some did not even follow it because they came to school late. The late students will be sanctioned by the teacher..

The study conducted by Noor Hidayat in 2016 shows that implementation of character education through the habituation was experienced by him and the santris everyday. First, the santris got used to doing Salat fardhu in jama'ah five times a day in masjid and in dormitory. Second, the santris got used to having meal on time, they got used to the morning exercise after doing Salat shubuh and the other habituation.

The study conducted by Eko Budi Prasetyo UPI published in 2017 shows that the instillation of asmaul husna values constitutes the actualization of the vision of the school, i.e. Creating the Excellent, Religious, and Environment-Friendly School as well as realization of one of the school goals, i.e. The building of the school members character 
founded by 7 basic values, i.e. honesty, responsibility, visionary, self-disciplines, cooperativeness, justice, and careness.

Based on the explanation above, the problems in the research are: (1) How the character education to improve the students' self-discipline was implemented through Asmaul Husna recitation habituation to grade IV students of SD Negeri Purwoyoso 01, (2) What are the obstructions to the implementation of character education through Asmaul Husna recitation habituation to grade IV students of SD Negeri Purwoyoso 01, (3) What are the encouragement to the implementation of character education through Asmaul Husna recitation habituation to grade IV students of SD Negeri Purwoyoso 01, (4) Whether the implementation of character education through Asmaul Husna recitation habituation has impact on character improvement of grade IV students of SD Negeri Purwoyoso 01.

The study aims to explain: (1) process of the implementation of character education to improve the students' self-discipline through Asmaul Husna recitation habituation to grade IV students of SD Negeri Purwoyoso 01, (2) identification of the obstacles to the the implementation of character education through Asmaul Husna recitation habituation to grade IV students of SD Negeri Purwoyoso 01, (3) the things encouraging the implementation of character education through Asmaul Husna recitation habituation to grade IV students of SD Negeri Purwoyoso 01, (4) the implementation of character education through Asmaul Husna recitation habituation has impact on the character of grade IV students of SD Negeri Purwoyoso 01.

\section{Research Methods}

The study is the qualitative descriptive study with single case study of qualitative approach. Subjects of the research are the teacher and students, and the object of the research was Asmaul Husna recitation habituation. The data were collected through observation, semistructured interviews, documentation. The study used validity methods i.e. triangulation of data sources, member checking, and referential adequacy. The data were analyzed using content analysis. Content analysis is very general. Berg (quoted by Ulfatin, 2015 :242) stated that content analysis is the analysis process that changes the results of interviews, field notes, and various information on data into systematic information.
The content analysis exposes three things, i.e. objectivity, systematics, and generalization. In the study, I will described the studied subject systematically and then generalize it based on the facts found in the field.

\section{Results And Discussion}

\section{Disciplines as Students' Character in SDN Purwoyoso 01 Ngaliyan}

Tulus Tu'u (2008:31) stated that discipline is something united in somebody's self. Discipline is integral part of one's life appearing in daily life. Discipline emerged and was built as the results and the impact of long establishment carried out in the family and then continues in the education at school. Discipline is required by anyone at anytime. It is because anywhere somebody is, there is always rules or order.

Grade IV students' self-discipline when engaging in the habituation of Asmaul Husna was good enough. It was shown by the fact that a few students knew Asmaul Husna very well and were enthusiastically engaged in the habituation of Asmaul Husna. Some students, however, came late so they were not engaged in from the beginning. Notes during the research: the students came to school on time, only a few came late, the students were engaged in Asmaul Husna habituation in order, the students' enthusiasm to Asmaul Husna habituation process was high, the teacher monitored and led during Asmaul Husna habituation.

\section{Implementation of Character Building through Habituation}

Mulyasa (2014) revealed that Character education was not merely teaching the right from wrong. More than that, character education instills the habits (habituation) of the good things so that the students comprehend the right from wrong, can feel the good values and get used to doing it. School is a strategic place to implement the character education in terms of developing and building the students' character.

Asmaul Husna habituation is the measure taken by the school to integrate the character education into the daily activities at school planned by the school. The character education had been implemented well to grade IV students of SDN Purwoyoso 01. During that activity, the students were 
enthusiast and happy. They then tried to come to school on time.

The finding is relevant to the study conducted by Anis Ibnatul Muthoharoh. During the habituation activities, the students have showed enthusiasm delightfully and happily.

The study was relevant with Peraturan Menteri Pendidikan dan Kebudayaan Republik Indonesia Nomor 23 Tahun 2015 (Regulation of Minister of Education and Culture: 23/2015) on Character Building with Mercy of The One and Only God Article 1 "Pembiasaan adalah serangkaian kegiatan yang harus dilakukan oleh siswa, guru, dan tenaga kependidikan yang bertujuan untuk menumbuhkan kebiasaan yang baik dan membentuk generasi berkarakter positif" (Habituation is a series of activities that must be done by the students, the teacher, and educational staff in order to grow the good habits and to build the generation with positive character).

\section{Obstruction to the Implementation of Nadzam Asmaul Husna recitation habituation}

Character education to improve the students' self-disciplines through Asmaul Husna recitation habituation has experienced the obstruction in the implementation, i.e. the fact that the school life is different from the home life; the teachers with different faiths could not guide the students best to get engaged in the Asmaul Husna recitation habituation; some students still came to school late; as well as the facilities and infrastructure sometimes did not function well.

Based on the study conducted by Eko Budi Prasetyo published in 2017 titled "Implementasi Pembiasaan Nilai-Nilai Asmaul Husna di SMAN 2 Serang dalam Pembentukan Karakter Religius Siswa" (Implementation of Habituation of Asmaul Husna Values in Terms of Religious Character Building of Students of SMAN 2 Serang) I found that the condition of the supporting facilities such as sound systems, sometimes did not function well, thus, the implementation of habituation of Asmaul Husna values did not work well.

Based on the description above, he drew a conclusion that in the implementation of character education, there were some obstacles. Those can be humanly, instructional, or institutional ones.

\section{The promotion to the Implementation of Nadzam Asmaul Husna recitation habituation}

The thing that supported the implementation of character education in SDN Purwoyoso 01 was the good role of the teacher in terms of guiding and giving good examples to the students, mainly the good example for self-discipline. The teacher was the main factor to the success of character education and existence of the order supporting the students' character building.

Another relevant study is the one published in 2016, conducted by Nur Hidayat titled "Implementasi Pendidikan Karakter Melalui Pembiasaan Di Pondok Pesantren Pabelan" (Implementation of Character Education through Habituation in Pondok Pesantren Pabelan). There, in pesantren Pabelan, the board really educated and instilled the values of good character to the santris and put the confirm order and rules into effect, and the santris must obey them.

A student's self-awareness also plays important role in promoting the spirit of selfdisciplines through Asmaul Husna recitation habituation. As the awareness of spirit of selfdiscipline grows inside somebody naturally, instead of due to compulsion. Based on the observation I made in the field, I found that partly students had high self-awareness. Selfawareness is the main pillar to student's selfawareness raising.

\section{Impact of Nadzam Asmaul Husna recitation habituation to the students character \\ In SD Negeri Purwoyoso 01 Asmaul} Husna recitation habituation as the inspiration for the students to know the names of Allah SWT as well as to learn from Him, hence, the good character can be built in each student. Every teacher always tries to instill the values and the meaning of Asmaul Husna to the students. Learning character of Allah contained in Asmaul Husna does not mean to rival God, but it means that the teacher seeks to build an individual with good character.

Another relevant study conducted by Riski Hayatun published in 2017 titled "Pengaruh Pembacaan Asmaul Husna terhadap Sikap Spiritual Siswa Kelas VII di 
MTsN Karanganyar" (Impact of Asmaul Husna Recitation on Spiritual Attitude of Grade VII Students of MTsN Karanganyar) shows that Asmaul Husna recitation had greater impact on spiritual attitude than when it is not recited. It is caused by internal factor (fitrah) and external factor (family, school and surrounding people) and Asmaul Husna recitation habituation three times a week could improve the students' spiritual attitude and its change.

Thus, I can draw a conclusion that the good character building cannot be carried out merely by reciting and memorizing Asmaul Husna, but we also need to take measures to learn character of Allah SWT included in Asmaul Husna. Then those characters are practiced and habituated in daily life.

\section{Conclusion}

Self-discipline of grade IV students of SDN Purwoyoso 01 when being engaged in Asmaul Husna recitation habituation is good so far, nevertheless a few students still came to school late, so they did not participate in Asmaul Husna recitation habituation from the beginning. They were engaged in Asmaul Husna recitation habituation enthusiastically and happily. The students tried to come to school on time. The obstruction of the implementation was the fact that the school life was different from the life at home, a few students came late, and insufficient facility and infrastructure. The supporting factor to implementation of Asmaul Husna recitation habituation to grade IV students of SDN Purwoyoso 02 was the great role that the played in terms of guiding and giving good example to the students, mainly being good model for selfdiscipline. In SDN Purwoyoso 01 Asmaul Husna recitation habituation functions as inspiration for the students to know well the good names of Allah SWT as well as to learn them so the good character can be built inside individual students.

\section{References}

Ahmad Suriansyah. 2015. Strategi Kepemimpinan Kepala Sekolah, Guru, Orangtua, dan Masyarakat dalam Membentuk Karakter Siswa. Jurnal Cakrawala Pendidikan. Vol 34. No 2.

Anis Ibnatul M. Pendidikan Nasionalisme Melalui Pembiasaan di SD Negeri Kuningan Semarang Utara. Semarang :
Universitas Negeri Semarang(diunduh 28 Januari 2018).

Bonita. J. 2009. Character education and student discipline in selected elementary schools

EkoBudiPrasetyo.2017. 'Implementasi Pembiasaan Nilai-Nilai Asmaul Husna di SMAN 2 Kota Serang dalam Pembentukan Karakter Religius Siswa". Bandung : Universitas Pendidikan Indonesia (diunduh pada 9 Maret 2018).

Matthew and David. 2010 . Student Discipline Problems and the Transition From Elementary to Middle School(diunduh pada tanggal 17 Maret 2018)

Miray . 2014. The effect of child activity on the habituation attitude of reading book which of child's parents (diunduh pada tanggal 17 Februari 2018)

Mulyasa.2014. Manajemen Pendidikan Karakter. Jakarta : PT BUMI AKSARA

Nur Hidayat. 2016.” Implemenatasi Pendidikan Karakter melalui Pembiasaan di Pondok Pesantren Pabelan". Jurnal Pendidikan Sekolah Dasar. Vol 2 No 1.

Peraturan Presiden Nomor 87 Tahun .2017. Penguatan Pendidikan Karakter. Jakarta.

Peraturan Menteri Pendidikan dan Kebudayaan Republik Indonesia Nomor 23 Tahun 2015 tentang Penumbuhan Budi Pekerti dengan Rahmat Tuhan yang Maha Esa.Jakarta

Riski Hayatun.2017. "Pengaruh Pembacaan Asmaul Husna terhadap sikap spiritual Siswa MTsN Karanganyar". Skripsi. Surakarta: Program Sarjana IAIN Surakarta.

Sugiyono, 2015. Metode Penelitian Pendidikan: Pendekatan Penelitian Kuantitatif, Kualitatif, dan $R \& D$. Bandung: CV.ALFABETA.

Syaiful Ridho. 2012. Pengembangan Nilai Karakter Konservasi Berbasis Pembelajaran. Jurnal Penelitian Pendidikan Vol 29. No.2.

Tu'u, Tulus.2008.Peran Disiplin Pada Perilaku dan Prestasi Siswa.Jakarta: PT Grasindo.

Ulfatin, Nurul. 2015. Metode Penelitian Kualitatif di Bidang Pendidikan. Malang : Media Nusa Creative.

Wuryandani, Wuri. 2014. "Pendidikan Karakter Disiplin di Sekolah Dasar". Jurnal Cakrawala Pendidikan, 33(2):288-289.

Zubaedi. 2015. Desain Pendidikan Karakter. Jakarta: KENCANA PRENADA MEDIA GROUP. 